\title{
Temporal Evolution of Nitrogen and Phosphorus of Agricultural Non- point Source in Haikou City
}

\author{
X.Chen, B.B.Liu, L.X.Peng, S.S.Huo, M.Chen, L.Wu \& K.B.Zhou \\ Environment and Plant Protection Institute, Chinese Academy of Tropical Agricultural Sciences/ \\ Environmental Assessment and Risk Analysis Center, Haikou, Hainan, People Republic of China \& Status of \\ The Observation in Environmental Science of Agricultural Department, DanZhou, Hainan,People Republic of \\ China
}

\begin{abstract}
The quantification of nitrogen and phosphorus nutrient loads is the primary task for the control of non-point pollution. In this study, the data between 2006 and 2011 were collected and analyzed in Haikou City. The results showed that the major agricultural non-point source structure was composed of nitrogen and phosphorus and the order was fertilizers > living sewage > animal feces in last 5 years in Haikou City. Constitute changes of nitrogen and phosphorus in agricultural non-point source suggested that the nitrogen and phosphorus contribution rate of fertilizer on agricultural non-point source declined, while residents of sewage, animal feces annually increased.
\end{abstract}

KEYWORD: Non-point source pollution; Nitrogen; Phosphorus; Temporal evolution

\section{GENERAL INSTRUCTIONS}

Agricultural non-point source pollution is one of main problems of water environment deterioration. Sources of pollutants include fertilizers and pesticides in agriculture and landscape, animal dung, bait unemployed in the aquaculture, etc.. To quantify the load of nitrogen and phosphorus and other nutrients is the primary task of non-point source pollution control. In the previous study, we found that the water quality was generally good in Hainan and the environmental level did not belong to a high risk area. However, compared to other cities in Hainan, the load intensity of nitrogen and phosphorus was higher in Haikou City, and the content of nitrogen and phosphorus reached $28.59 \%$ and $63.12 \%$ in Haikou City, respectively (Wu, 2013). It indicated that Haikou City is a potential risk area of non-point source pollution because of its large cultivated land and population.

In this paper, the relevant data of agricultural non-point nitrogen and phosphorus pollution were collected and analyzed to further forecast the risk rule of agricultural non-point nitrogen and phosphorus pollution in Haikou City and to know the space-time evolution of farmland non-point source nitrogen and phosphorus pollution. So as to provide a scientific basis for reasonable fertilization management measures for Haikou City agricultural development and identify key control area of agricultural non-point source pollution and environmental risk assessment of phosphates.

\section{GENERAL SITUATION AND DATA SOURCES}

\subsection{General situation}

Haikou City (N $19^{\circ} 32^{\prime}-20^{\circ} 05^{\prime}$, E $110^{\circ} 10^{\prime}-110^{\circ} 41^{\prime}$ ) is located in the north of Hainan Island, which is $2304.84 \mathrm{~km}^{2}$. It is not only the center of political, economic, technological and cultural in Hainan Province, but also equipped with the city service function and convenient transportation, in which terrain is slightly long heart, topography is gentle and shrub grass is the main vegetation. Haikou City is the north coastal area with sea area $830 \mathrm{~km}^{2}$ and coastline length $131 \mathrm{~km}$. The city is at low latitudes in tropical north and belongs to the tropical marine climate. Nan Du River which is the longest river of the island crosses the city central site into the sea. The soil area is approximately 3,084,000 hectares in Hainan Province, which contains 53.42\% latosol soil, $3.56 \%$ yellow soil of the total area. In addition, the rest of the natural soil is made up of dry clay, coastal sand and volcanic ash soil.

\subsection{Data sources}

The original data, such as crop acreage and yield, fertilizer use, livestock production and population in this paper, were from Haikou City statistical yearbook in 2006-2011. The original data which in the table 1 and table 2 were carried out with output coefficients (Zhou, 2011; Reckhow \& Simpsm,1980; Cooper, 1990) and removal efficiency (Worrall, 1999; Lowrence,1984; Osborne,1993) of nitrogen 
and phosphorus of farmland in order to make a comparison.

Table 1. Nitrogen and phosphorus output coefficients and vegetation removal efficiency.

\begin{tabular}{|l|l|l|l|}
\hline Type & $\begin{array}{l}\text { TN } \\
(\mathrm{t} \cdot \text { ha-1) }\end{array}$ & $\begin{array}{l}\text { TP } \\
(\mathrm{t} \cdot \text { ha-1) }\end{array}$ & Removal efficiency $(\%)$ \\
\hline Farmland & 0.372 & 0.364 & 25 \\
\hline
\end{tabular}

Table 2. the rural population and livestock output coefficient.

\begin{tabular}{|c|c|c|c|c|c|}
\hline & $\begin{array}{c}\text { Livestock } \\
\left(\mathrm{t} \cdot 10^{-4} \cdot \mathrm{a}^{-1}\right)\end{array}$ & $\begin{array}{c}\text { Poultry } \\
\left(\mathrm{t} \cdot 10^{-4} \cdot \mathrm{a}^{-1}\right)\end{array}$ & $\begin{array}{c}\text { Sheep } \\
\left(\mathrm{t} \cdot 10^{-4} \cdot \mathrm{a}^{-1}\right)\end{array}$ & $\begin{array}{c}\text { Pig } \\
\left(\mathrm{t} \cdot 10^{-4} \cdot \mathrm{a}^{-1}\right)\end{array}$ & $\begin{array}{c}\text { Population } \\
\left(\mathrm{t} \cdot 10^{-4} \cdot \mathrm{a}^{-1}\right)\end{array}$ \\
\hline TN & 113.71 & 0.459 & 15.13 & 26.67 & 19.55 \\
\hline TP & 2.18 & 0.054 & 0.45 & 1.42 & 2.14 \\
\hline
\end{tabular}

\section{THE ANALYSIS OF ECOLOGICAL CITY EVALUATION}

\subsection{The changes of nitrogen and phosphorus in agricultural non-point source with time}

The results showed that nitrogen and phosphorus content in cultivated land decreased from 2006 to 2011 in Haikou City (Fig. 1). Total nitrogen content changed between 12000-13500t with average decline rate of $1.19 \%$, and the highest fall was $3.02 \%$.

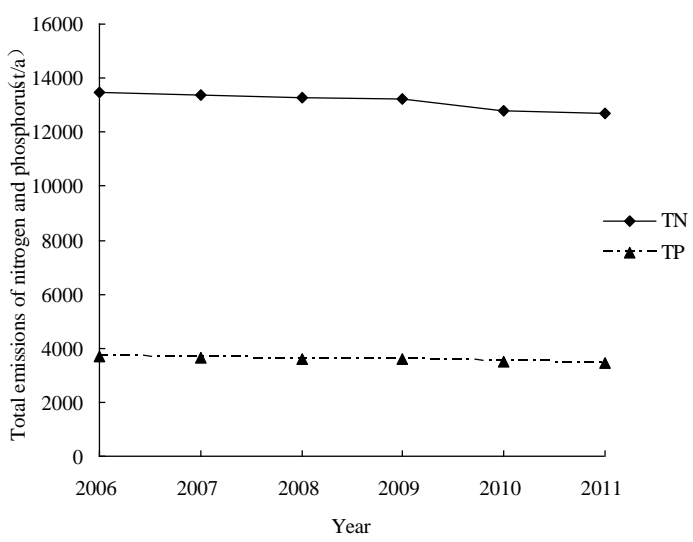

Figure1.The changes of nitrogen and phosphorus fertilizers from farmland fertilizer in Haikou City with time.

For another hand, total phosphorus content varied between 3400t and 3700t, and decline rate and the highest fall were the same as that of total nitrogen content. Compared with the data of 2005, the total nitrogen content dropped 787.61t and total phosphorus reduced $215.02 \mathrm{t}$ in 2011.

In fluctuating fertilizer, the content of nitrogen was turn to a downward trend with annual average decline rate of $3.75 \%$ from 2006 to 2011 (Fig. 2), and the largest decline of which was $17.89 \%$ in 2007, while the largest increase was $16.33 \%$ in 2008. Phosphorus content in fertilizers slowly went down with an average decline of $4.57 \%$.

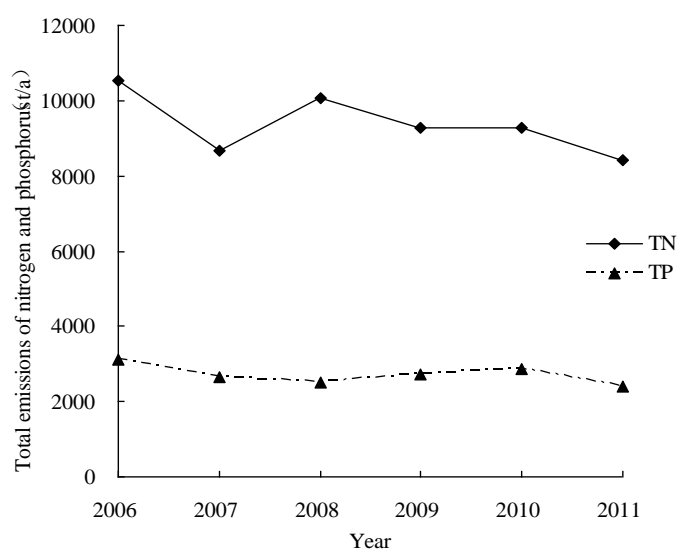

Figure2.The variation of nitrogen and phosphorus fertilizer inputs in Haikou City with time.

The results suggested that nitrogen and phosphorus content in residents discharges increased from 2006 to 2011 with an average annual growth rate of $3.87 \%$ (Fig. 3). The results also showed that nitrogen and phosphorus content in livestock manure sharply decreased with a rate of $30.12 \%$ from 2006 to 2007 , while the content grew with a rate of $8.28 \%$ by year from 2007 to 2011 (Fig.4).

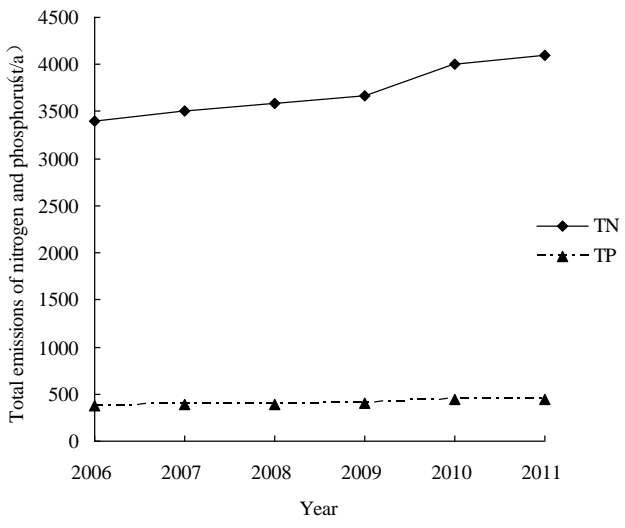

Figure3.The changes of total emissions in manure nitrogen and phosphorus in Haikou City with time.

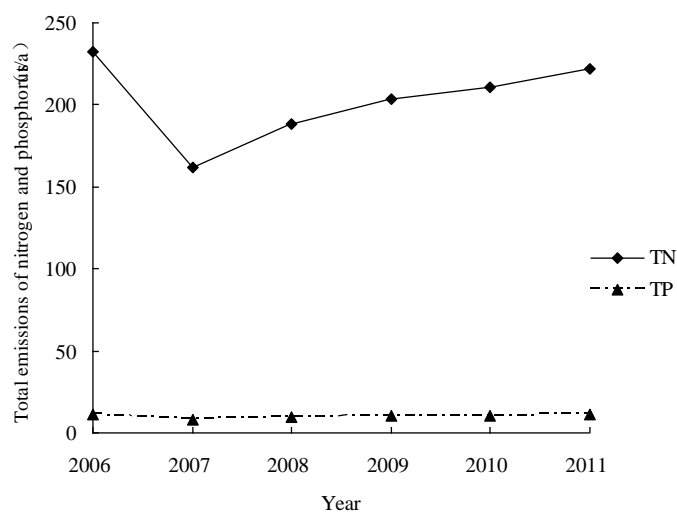

Figure4.The changes of total nitrogen and phosphorus emissions from sewage in Haikou City with time. 


\subsection{Structural analysis of agricultural non-point source nitrogen and phosphorus sources}

The result showed that Major agricultural non-point source structure composed of nitrogen and phosphorus were fertilizers > living sewage > animal feces in last 5 years in Haikou City.

Table 3.The contribution of Nitrogen of non-point source.

\begin{tabular}{|c|c|c|c|}
\hline \multirow{2}{*}{ Year } & \multicolumn{3}{|c|}{ Nitrogen contribution rate } \\
\cline { 2 - 4 } & Fertilizer inputs & Livestock manure & Residents sewage \\
\hline 2006 & $78.17 \%$ & $1.72 \%$ & $25.18 \%$ \\
\hline 2007 & $64.77 \%$ & $1.21 \%$ & $26.25 \%$ \\
\hline 2008 & $75.97 \%$ & $1.42 \%$ & $27.06 \%$ \\
\hline 2009 & $70.12 \%$ & $1.54 \%$ & $27.81 \%$ \\
\hline 2010 & $72.41 \%$ & $1.65 \%$ & $31.23 \%$ \\
\hline 2011 & $66.25 \%$ & $1.75 \%$ & $32.28 \%$ \\
\hline
\end{tabular}

Table4. The contribution of Phosphorus of non-point source.

\begin{tabular}{|c|c|c|c|}
\hline \multirow{2}{*}{ Year } & \multicolumn{3}{|c|}{ Phosphorus Contribution rate } \\
\cline { 2 - 4 } & Fertilizer inputs & Livestock manure & Residents sewage \\
\hline 2006 & $84.43 \%$ & $0.31 \%$ & $10.10 \%$ \\
\hline 2007 & $72.65 \%$ & $0.22 \%$ & $10.52 \%$ \\
\hline 2008 & $69.27 \%$ & $0.26 \%$ & $10.85 \%$ \\
\hline 2009 & $75.25 \%$ & $0.28 \%$ & $11.15 \%$ \\
\hline 2010 & $81.63 \%$ & $0.30 \%$ & $12.52 \%$ \\
\hline 2011 & $69.07 \%$ & $0.32 \%$ & $12.94 \%$ \\
\hline
\end{tabular}

\section{CONCLUSIONS AND COUNTERMEASURES}

Haikou City has rainy weather and the Nandu River crosses the region. It is the political, economic and cultural center in Hainan Province with the characteristics of large population proportion, arable land and large crop intensity per unit area. It is known that farming, livestock and aquaculture pesticides and fertilizers can cause regional agricultural non-point source pollution.

In this study, we found that fertilizers, living sewage and manure were the major nitrogen and phosphorus source of agricultural non-point source in Haikou City and the contribution ratio for these three sources were fertilizers > living sewage > manure between 2006 and 2011. The further study of its timing changes in these years showed that the contribution rate of fertilizer for agricultural nonpoint source nitrogen and phosphorus declined, while residents of sewage, manure emissions increased annually, which indicated that government had good effect on controlling the application of pesticides and fertilizers. However, the use of water resources still lags behind.

Therefore, in order to prevent the generation of agricultural non-point source pollution, it has some suggestions as follows:
(1)The agricultural production sector should optimize and adjust the agricultural structure, for example, standardizing and regulating the emissions from livestock and aquaculture, improving the efficiency of the pesticides and fertilizers use, strengthening the regional vegetation construction, improving the vegetation nutrients nitrogen and phosphorus retention, reducing the output load of nitrogen and phosphorus.

(2) The agricultural regulators should increase the quality of supervision of agricultural products and control the quantity of pesticides and fertilizers on agricultural sources to avoid farmland pollution.

(3) The local governments should promote environmental knowledge and strengthen residents' environmental awareness, such as water conservation, water purification, water repeatedly and so on.

(4) The environmental management departments should improve the emission standards and strengthen environmental legislation and management.

\section{ACKNOWLEDGMENTS}

This work was financially supported by the Fundamental Research Funds for Environment and Plant Protection Institute, CATAS (No.1630042014004).

\section{REFERENCES}

[1] Z. Wu, X. Chen, B b. Liu, et al. 2013. Risk assessment of nitrogen and phosphorus loads in Hainan Island based on InVEST model. Chinese Journal of Tropical Crops. Vol.34 (9): 1791-1797.

[2] S c. Zhou, Y m Song, R Wang, et al. 2011. Characteristics of Agricultural Non-point Source Pollution in Bioclimatic Division in Hainan Island, China. Journal of Agro-Environment Science. Vol. 30(8):1660-1668.

[3] Reckhow K H, Simpson J J. 1980. Aprocedure using modeling and error analysis for prediction of lake phosphorus concentration from land use information. Canadian Journal of Fisheries and Aquatic Sciences. Vol.37: 1439- 1448.

[4] Cooper A B. 1990, Nitrate depletion in the riparian zone and stream channel of a small headwater catchment. Hydrobiologia. Vol.202: 13-26.

[5] Worrall F, Burt T P. 1999. The impact of land-use change on water quality at the catchment scale: the use of export coefficient and structural models. J Hydrol, Vol.221: 7590 .

[6] Lowrence R R, Todd R L, Fail J, et al. 1984, Riparian forests as nutrient filters in agricultural watersheds. Bioscience. Vol. 34(8): 374-377.

[7] Osborne L L, Kovacic D A. 1993. Riparian vegetated buffer strips in water-quality restoration and stream management. Freshwater Biology. Vol. 29(2): 243-258. 